\title{
Timber Skidding with Mules to Karstic Areas in Mediterranean Region of Turkey *Tolga ÖZTÜRK ${ }^{1}$, Necmettin ŞENTÜRK ${ }^{1}$
}

\author{
${ }^{1}$ Istanbul University, Faculty of Forestry, Department of Forest Construction and \\ Transportation, 34473, Bahcekoy/Istanbul/Turkey \\ *Corresponding author: tozturk@istanbul.edu.tr
}

Received Date: 18.01.2017

Accepted Date:08.03.2017

\begin{abstract}
Timber skidding may be done with mules when terrain's slope and skidding distance is small. Animal skidding operations is one of the traditional hauling systems in some regions of Turkey. But, the use of mules in skidding operation is very decreases in recent years. This paper present research results of the productivity of mules skidding using timber harvesting method in karstic region of Turkey. Time measurements are done during skidding operations with mules. The elements of the skidding work phases were identified, 30 cycles were recorded for this study, skidding distance, slope, number of timber and stem size. In this study, skidding distances are changed between 105 and 154 meters. The average skidding distance is 135 meters. Hourly productivity is $1.142 \mathrm{~m}^{3} \mathrm{hr}^{-1}$ for average skidding distance. The total cost of mules skidding operations is calculated as $11.55 \$ \mathrm{~m}^{3-1}$.
\end{abstract}

Keywords: Mule, skidding, productivity, karstic region

\section{Türkiye’nin Akdeniz Bölgesindeki Karstik Alanlarda Katırlar ile Tomruğun Sürütülmesi}

Özet: Tomruğun sürütülmesi arazi eğimi ve sürütme mesafesi az olan alanlarda katırlar ile yapılabilmektedir. Hayvanlarla sürütme çalışmaları Türkiye'nin bazı bölgelerinde geleneksel bölmeden çıarma sistemlerinden biri olarak kullanılmaktadır. Fakat, son yıllarda sürütme çalışmalarında katırların kullanımı çok azalmıştır. Bu çalışmada Türkiye'nin karstik yapıya sahip alanlarında tomruk üretim metodu kullanılarak katırlarla sürütmenin verimliliği araştırılmıştır. Katırlarla sürütme çalışmalarında zaman etüdleri yapılmıştır. Sürütme iş aşamalarındaki safhalar tanımlanmış ve sürütme mesafesi, eğim, sürütülen tomruk sayısı ve gövde hacmi olmak üzere toplam 30 adet etüd yapılmıştır. Bu çalışmada sürütme mesafesi 105 ve $154 \mathrm{~m}$ arasında değişiklik göstermiştir. Ortalama sürütme mesafesi $135 \mathrm{~m}$ olarak alınmıştır. Katırların saatlik verimi ortalama sürütme mesafesine göre $1.142 \mathrm{~m}^{3} \mathrm{hr}^{-1}$ olarak bulunmuştur. Katırların sürütme toplam maliyeti ise $11.55 \$ \mathrm{~m}^{3-1}$ olarak tespit edilmiştir.

Anahtar kelimeler: Katır, sürütme, verimlilik, karstic bölge

\section{Introduction}

Skidding and transporting by animals are labor intensive operations. For many countries, various species of animal have been used to such as oxen, donkeys, mules, horses, elephants, lamas and yaks (Dykstra and Heinrich, 1996). Especially, oxen and buffalos are very strong, besides they are easy to drive in harvesting areas. Mules and horses are weaker according to oxen and buffalos. Horses are suitable for cold weather, whereas mules can work better than horses in hot weather (Shrestha and Lanford, 2005). In Turkey, animal skidding is still performed to the some regions and mules are preferred to hot conditions in Mediterranean region. Mules can provide a successful solution on karst regions and they are generally used on the skid paths. Mule is used to harvesting on steep terrains without forest roads (Naghdi et al., 2009).
Animals were the only source of power for skidding and hauling in timber harvesting. Especially, before the invention of forest machines, this power was the main source of transport in the worldwide (Jourgholami, 2011). Skidding and hauling by animals are limited to small timber, fuelwood and pulpwood. The powers of mules are limited. The productivity of animals is affected according to terrain condition, type of product, maintenance requirements and weather conditions. Animal skidding can be particularly advantageous for thinning or pulpwood harvesting, where relatively small $\log$ are to be extracted or where products from pit sawing or other onsite processing are to be transported (Jourgholami et al., 2010). Animal logging may become efficient in the case of very dense stands from which results small logs such as the first thinning (Borz and Ciobanu, 2013). Fixed cost components include the 
investment cost of the animal or team, double head yoke, logging chains, and any other investments with a life more than a year (Akay, 2005). Animal logging is used because of the insufficient forest road network, lack of mechanized equipment, steep terrain, small harvest areas, and low harvest volume, as well for environmental protection (Ezzati et al., 2011).

In this study, the productivity of mules in harvesting area is investigated on Mediterranean region. Also, the skidding operations by mules investigated to effects on the forest soil and ground.

\section{Materials and Methods}

The skidding operation of Turkish red pine (Pinus brutia Ten.) timber was carried out with

mules in Pinarcik Forest Enterprise within the Finike Forest Administration, Antalya. Study area is located the mountainous area of Mediterranean Sea Region in Turkey (Figure 1). The total forest area Pinarcik Forest Enterprise is 10080 ha and the commercial tree species in this region include Pinus brutia Ten., Cedrus libani A.Rich. and Juniperus sp.. The elevation ranges from 700 $\mathrm{m}$ to $1100 \mathrm{~m}$ with the ground slopes of $20 \%$ to $100 \%$. The study area consists of Type B forest roads with the density of $15 \mathrm{~m} / \mathrm{ha}$. The study area is located on the Toros Mountains, which is the largest and most important karst region in Turkey. According to Boydak (2003), this region has one of the most complex karst circulation system and rough terrain characteristics such as sharp peaks, deep valleys, and narrow gorges. Due to immediate penetration of rainfall and snow melt into the rock crack system, surface soil formation very slowly occurs along the cracks and stratification surfaces of the limestone (Boydak, 2003). The research was carried out in compartment number 157 of Pinarcik Forest Enterprise, with the altitude ranging between 750 and 850 meters, above the sea level and lies on a south aspect. Soils of this region are terra rossa.

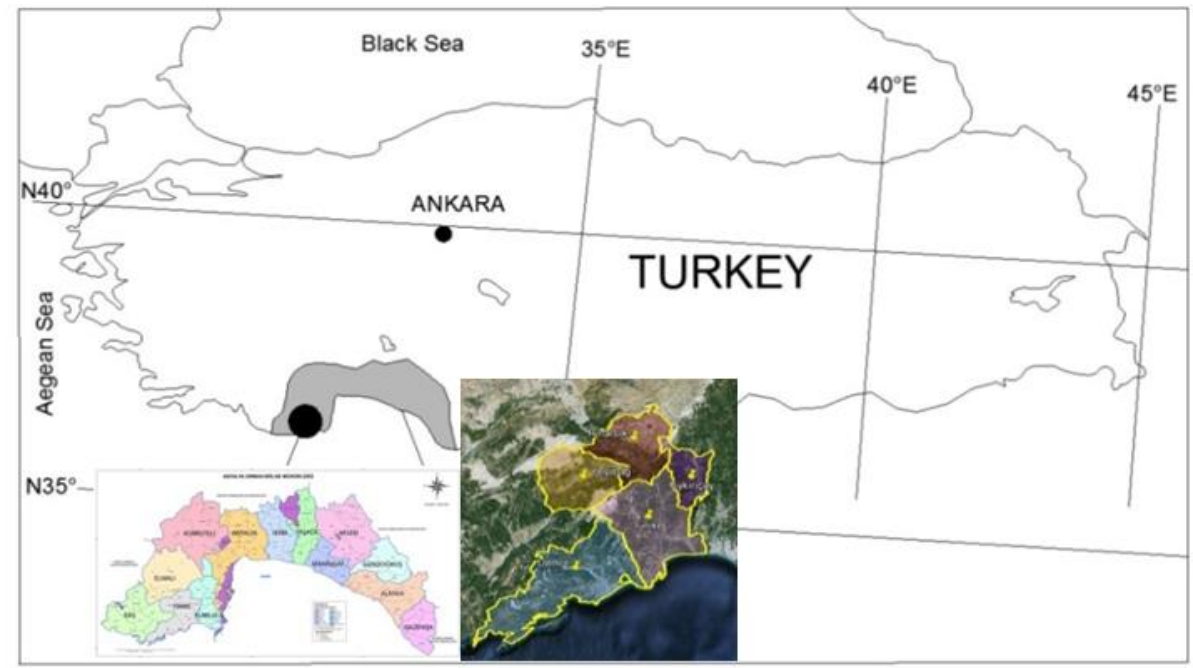

Figure 1: Study area

Skidding of the timber was performed with mules in study area. Skidding operations were carried out on skid trail. All skidding operations were favorable (loaded downhill and unloaded uphill) and slope of skid trail was changed between 2 and 12 percent. The logging operation was performed by timber where the stems were skidded to the roadside landings by mules after the trees were felled, delimbed and topped at the stump area. Skidding logs are timber and length of skidding timber is changed between 2.5 and 4 meters.

\section{Data Collection}

For productivity of skidding operations with mules is done a time measurement. Detailed time studies were conducted to collect data on skidding cycles and delays. Time study is an important research tool used in comparing productivity at forest harvesting systems across 
varying conditions (McDonald and Fulton 2005). Time study is a set of procedures for determining the amount of time required, under certain standard conditions of measurement, for tasks involving some human, machine, or combined activity (Wang et al. 2003).

The repetition time study method was used to determining the production of mules. Cycle time for this study is taken form four elements. The time elements considered in the skidding phases include unloaded travel, hookup, loaded travel and unhook. Similar elements have been mentioned in various studies (Akay, 2005; Rodriguez, 1986; Ozturk and Senturk, 2010).

The time cycle phases are following as;

1. Unloaded travel: Time spent by the mule when they covered the distance from the landing area to the cutting area without a load.

2. Hookup: Time spent for hookup of load by workers.

3. Loaded travel: Time spent with the mule when they covered the distance from the cutting area to the landing area with a load.

4. Unhook: Time spent for unhook of load by workers.

Recorded data included productivity cycle time elements and other independent variables associated with each activity. Variables included skidding distance $(\mathrm{m})$, number of load and load volume $\left(\mathrm{m}^{3}\right)$ per turn. In this study, 30 work cycles were collected for skidding operation with mule.

\section{Results}

\section{Statistical Model}

In this study, SPSS 21.0 statistical programmer has been applied for developing regression equation of time measurements (Anonymous, 2012). Regression analysis has been realized with enter method. Summary for the total skidding cycles are shown in Table 1.
Table 1. Summary of time variables for skidding with mules

\begin{tabular}{lllll}
\hline Factors & Mean & $\begin{array}{l}\text { Stan.D } \\
\text { ev. }\end{array}$ & Min. & Max. \\
\hline $\begin{array}{l}\text { Unloaded } \\
\text { travel }\end{array}$ & 3.50 & 0.446 & 2.40 & 4.25 \\
\hline $\begin{array}{l}\text { Hookup of } \\
\text { load }\end{array}$ & 2.30 & 0.470 & 1.30 & 3.00 \\
\hline $\begin{array}{l}\text { Loaded } \\
\text { travel }\end{array}$ & 4.08 & 1.446 & 1.45 & 6.25 \\
\hline $\begin{array}{l}\text { Unhook of } \\
\text { load }\end{array}$ & 1.02 & 0.373 & 0.25 & 1.50 \\
\hline Total time & 11.30 & 1.754 & 7.50 & 13.20 \\
\hline $\begin{array}{l}\text { Skidding } \\
\text { distance }\end{array}$ & 135 & 14.755 & 105 & 154 \\
\hline $\begin{array}{l}\text { Load } \\
\text { volume }\end{array}$ & 0.219 & 0.062 & 0.127 & 0.334 \\
\hline $\begin{array}{l}\text { Number of } \\
\text { load }\end{array}$ & 2.4 & 0.774 & 1 & 3 \\
\hline
\end{tabular}

Total 30 skidding cycles were studied to develop a linear regression. The dependent variable is skidding time per cycle without delay (Total time $-\mathrm{T}$ ). A regression model developed from the detailed time study with mule was as follow:

$\mathrm{T}=-2.850+2.466 \times \mathrm{V}+0.100 \times \mathrm{SD}-0.331 \times$ NL

$\mathrm{T}=$ Skidding time $(\mathrm{min} / \mathrm{cycle})$

$\mathrm{SD}=$ Skidding distance $(\mathrm{m})$

$\mathrm{V}=$ Volume per cycle $\left(\mathrm{m}^{3}\right)$

$\mathrm{NL}=$ Number of load

In this analysis, skidding distance, number of load and load volume per cycle were entered in model at significant level 0.05 . The multiple correlation coefficients (R) are interpreted as $83 \%$ of total variability. The value of VIF is small (Table 2). Thus regression model is not multicollinearity. Autocorrelation was determined with Durbin Watson test. The Durbin Watson statistic fall within the range 1 to 2 in this study. The Durbin Watson statistic was 1.871 indicating a positive autocorrelation (Table 3).

Table 2: Statistical characteristics of models based on regression analysis

\begin{tabular}{lcccccc}
\hline \multirow{2}{*}{ Model } & \multicolumn{2}{c}{ Unstandadized Coefficients } & t & Sig. & \multicolumn{2}{c}{ Collinearity Statistics } \\
\cline { 2 - 3 } \cline { 6 - 7 } & B & Std.Error & & & Tolerance & VIF \\
\hline (Constant) & -2.850 & 1.477 & -1.929 & 0.065 & & \\
Volume & 2.466 & 2.420 & 1.019 & 0.318 & 0.870 & 1.150 \\
Skidding & 0.100 & 0.010 & 9.626 & 0.000 & 0.837 & 1.194 \\
distance & -0.331 & 0.188 & -1.761 & 0.090 & 0.929 & 1.076 \\
Number of load & & & & & & \\
\hline
\end{tabular}

a.Dependent Variable: Time 
Table 3: Values of models based on regression analysis

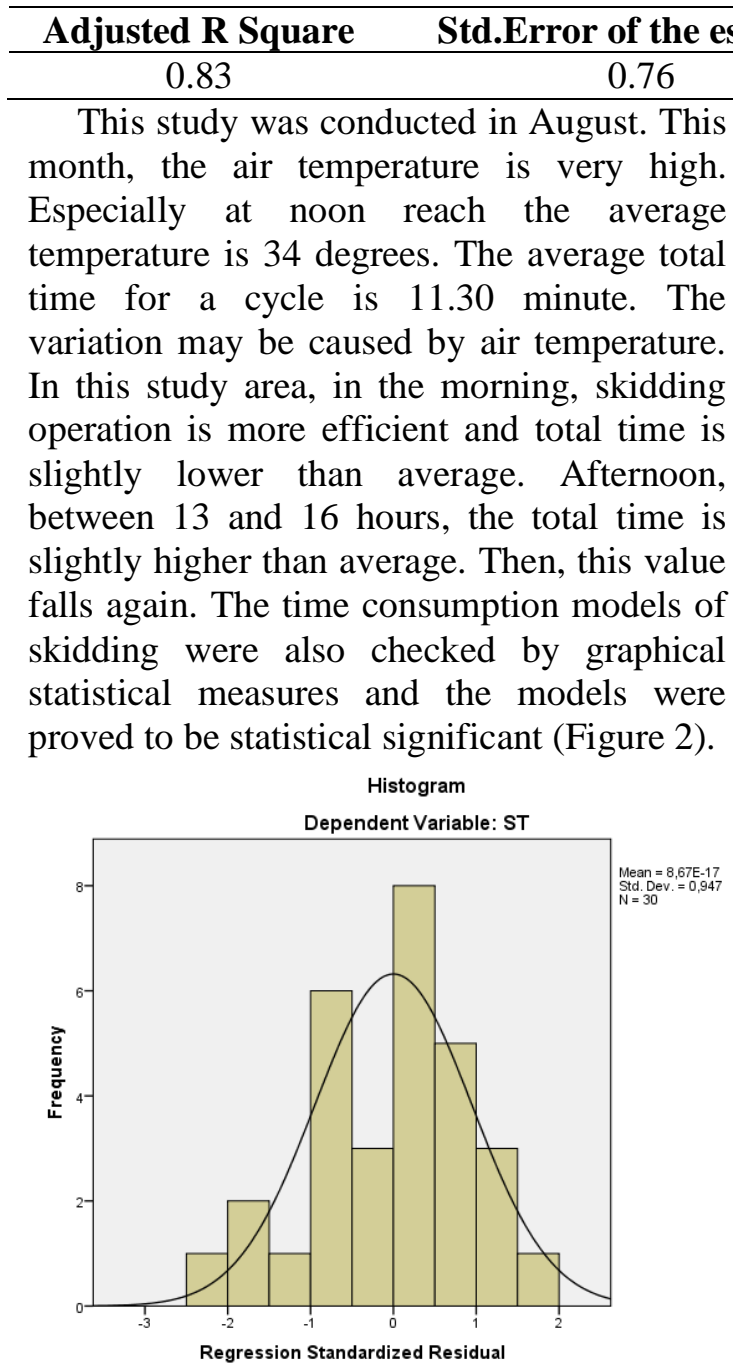

Figure 2: Histogram of standardized residuals of the overall time consumption model in skidding

\section{Productivity}

In this study, the hourly production for mule was $1.142 \mathrm{~m}^{3} \mathrm{hr}^{-1}$ and the average total cycle time was $11.30 \mathrm{~min}$ for average 135 meters skidding distance. The two most time consuming components of the total skidding time were unloaded travel and loaded travel. Daily average productivity rate of mule was calculated as $9.136 \mathrm{~m}^{3}$, approximately. The mule skidding operation inside harvesting area is shown Figure 3.

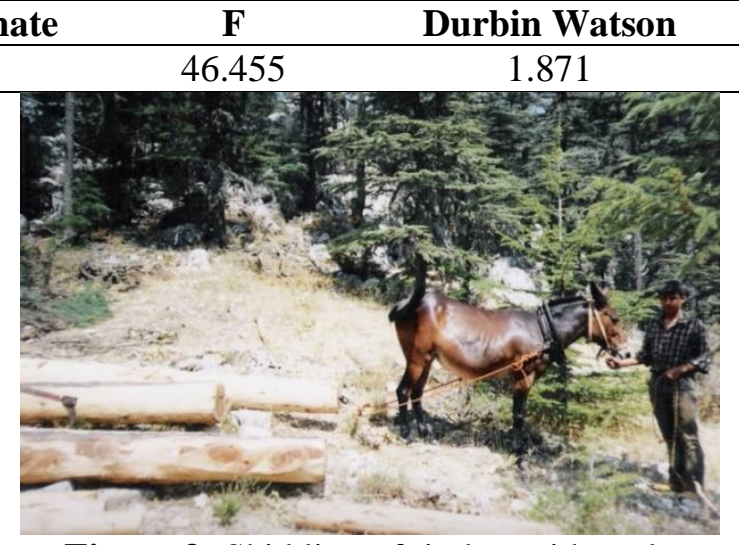

Figure 3: Skidding of timber with mule

\section{Analysis of Time Measurements}

In this study, the most time is spent skidding of timber with mule as $36 \%$ of total time. Total skidding time increased as the skid road distance increased. The skidding distance affected skidding cost. A summary of skidding operations with mule during the time study is shown in Table 4.

An inverse relationship of productivity with skidding distance and a direct relation with volume skidded are shown (Figure 4 $5)$. Therefore the highest productivity was found when the skidding distance was short and volume skidded was high. The average number of timber was 2, approximately, the average skidding distance $135 \mathrm{~m}$, and the average volume for a cycle was $0.219 \mathrm{~m}^{3}$.

Table 4: Total skidding cycle determined from the detail time

\begin{tabular}{|c|c|c|c|c|c|}
\hline$\underset{\Xi}{\stackrel{\Xi}{\Xi}}$ & 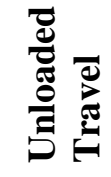 & 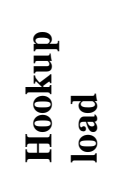 & 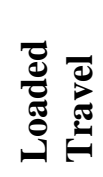 & 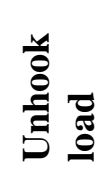 & 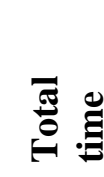 \\
\hline Minute & 3.50 & 2.30 & 4.08 & 1.02 & 11.30 \\
\hline Percent & 33.3 & 21.7 & 36.0 & 9.0 & 100 \\
\hline
\end{tabular}




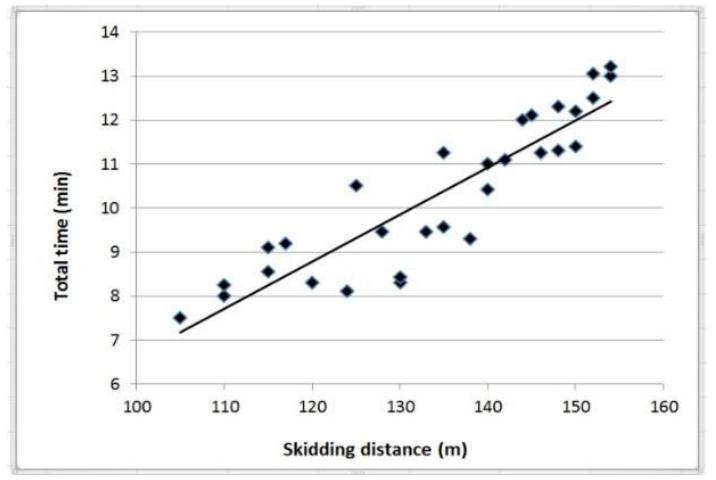

Figure 4: Relationship of skidding distance vs total time

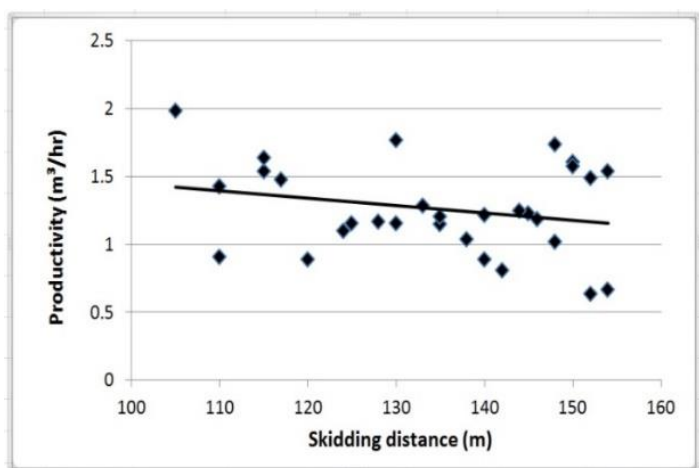

Figure 5: Relationship of skidding distance vs productivity

\section{Conclusion and Discussion}

This study shows the results from skidding red pine timber with the mules. The timber skidding was carried out downhill for a skid trail with the slopes of $2 \%$ to $12 \%$. In this study, productivity of mules was found to be $1.142 \mathrm{~m}^{3} \mathrm{hr}^{-1}$ for the average skidding distance of 135 meters. Daily productivity of mules in this research area was found to be $9.136 \mathrm{~m}^{3}$. In a similar study conducted by Mc Gonagli (1979) in Alabama, mule skidding operation was done in broad leaf and pine stands. The slopes of study area are changed together $0 \%$ and $6 \%$ and the average skidding distance was 125 meters. The productivity of this skidding operation was $17.172 \mathrm{~m}^{3} \mathrm{hr}^{-1}$. Another study, mule skidding in Kheyroud forest was studied in broad-leaf stands. In uphill and downhill skidding productivity for lumber was 1.0 and $1.2 \mathrm{~m}^{3}$ $\mathrm{hr}^{-1}$, respectively (Jourgholami et al., 2010). Jourgholami (2011) studied the productivity of mule logging in the Kheyrud Forest in Iran, the hourly production rates of hauling with mule was found to be $0.84 \mathrm{~m}^{3} \mathrm{hr}^{-1}$ and
$0.52 \mathrm{~m}^{3} \mathrm{hr}^{-1}$ for sawn-lumber and pulpwood, respectively. Another study, mule logging in Northern forests of Iran was studied in the Fageto-Carpinetum stand. The pulpwood hauling productivity was $1.246 \mathrm{~m}^{3} / \mathrm{hr}$ (Ghaffariyan et al., 2008). Eroglu and Ozmen (2010); productivity of mule was found $2.850 \mathrm{~m}^{3} \mathrm{hr}^{-1}$ and the average distance was 90 meters.

The results indicated that the productivity of mule in this study area was more than the productivity values from some studies and also, results were less than some studies. In this study, the average cost of mule skidding was calculated as $11.55 \$ \mathrm{~m}^{3-1}$. A similar study conducted in the harvesting area (Jourgholomi, 2011) reported that average cost of mule hauling was $15.47 \$ \mathrm{~m}^{3-1}, 25.00$ $\$ \mathrm{~m}^{3-1}$ and $30.66 \$ \mathrm{~m}^{3-1}$ for $50 \mathrm{~m}$ and $600 \mathrm{~m}$ skidding distances, respectively. Ghaffariyan (2008); the cost of mule hauling was found as 1.28 Euro $\mathrm{m}^{3-1}$ for pulpwood.

In this study, the mules during skidding operation was followed the contour lines in karst region. For skidding operations, skid trails didn't open for harvest in red pine stand. The one trail in harvesting area has occurred because of go and return of mules on the ground. In this study, environmental damages weren't showed. Because, the ground of region is very hard and amount of wear was occurred to be very small. On the ground was occurred just a trail. The erosion risk on the trails is very small in Mediterranean region where rainfall less than another region of Turkey. Besides, in this study, the soil compaction on skid trail wasn't showed. The similar a study, Naghdi et al. (2015) reported that mule hauling did not cause any deep soil disturbance and that bulk density increased with traffic intensity regardless of the skidding method used and the slope of the skid and mule trails. Another a study, Naghdi et al. (2009) reported that the soil compaction of surface soil $(0-10 \mathrm{~cm}$ depth) by animal logging was higher than by tractor logging. The use of animals for hauling operations has been shown to reduce soil compaction, soil disturbance and damage to residual trees significantly (McCabe and Tiner 1992; Rodriguez and Fellow, 1986; Wang, 1997). 


\section{References}

Akay A.E. 2005. Determining cost and productivity of using animals in forest harvesting operations. Journal of Applied Sciences Research, 1(2), 190-195.

Anonymous, 2012. IBM SPSS Advanced Statistics 21(Installation Cdrom).

Borz S.A., Ciobanu V. 2013. Efficiency of motor manual felling and horse logging in small-scale firewood production. African Journal of Agricultural Research, 8(24), 3126-3135.

Boydak M. 2003. Regeneration of Lebanon cedar (Cedrus libani A.Rich.) on karstic lands in Turkey. Forest Ecology and Management, 178, 231-243.

Dykstra D.P., Heinrich R. 2006. FAO Model code of forest harvesting practice. FAO Publication, Rome.

Eroglu H., Ozmen T. 2010. A research on the logging operation with animal power in terms of productivity. III. National Blacksea Forestry Congress, Artvin, Turkey, 554-563.

Ezzati S., Najafi A., Durston T. 2011. Impact of animal logging on soil physical properties in mule trail in Hyrcanian forests. Transportation Research Part D, 16, 316-320.

Ghaffariyan M.R., Durston T., Sobhani H., Mohadjer M.R.M. 2008. Mule logging in northern forests of iran: a study of productivity, cost and damage to soil and seedlings. Croat. J.For.Eng., 29(1), 67-75.

Jourgholami M., Majnounian B., Feghhi J., Visser R.J.M. 2010. Timber extraction with mules: a case study in the Hyrcanian forest. African Journal of Agricultural Research, 5(22), 3108-3115.

Jourgholami M. 2011. Small-scale timber harvesting: mule logging in Hyrcanian forest. Small-Scale Forestry. DOI 10.1007/s118420119174-y.

McCabe P.P., Tiner E. 1992. Mule logging: A dying art? Treasures Forest, 1415.

McDonald T.P., Fulton J.P. 2005. Automated time study of skidders using global positioning system data. Computers and Electronics in Agriculture, 48, 19-37.

Mc Gonagli K. 1979. Southern horse and mule logging in Alabama. Logging System Guide, US Forest Service.
Naghdi R., Lotfalian M., Bagheri I., Jalali A.M. 2009. Damages of skidder and animal logging to forest soils and natural regeneration. Croat. J.For.Eng., 30(2), 141149.

Naghdi R., Solgi A., Zenner E.K. 2015. Soil disturbance caused by different skidding methods in mountainous forests of Northern Iran. International Journal of Forest Engineering, 26(3), 212-224.

Ozturk T., Senturk N. 2010. Productivity and time studies of MB Trac 900 tractor at beech stands on mountainous areas in Turkey. Baltıc Forestry, 16(1), 132-138.

Rodriguez E.O. 1986. Wood extraction with oxen and agricultural tractors. Food and Agriculture Organization of the United Nations, 92, Rome.

Shrestha S.P., Lanford,B.L. 2005. Utilization and cost of log production from animal logging operations. Journal of Forest Engineering, 16(2), 167-180.

Wang L. 1997. Assessment of animal skidding and ground machine skidding under mountain condition. Journal of Forest Engineering, 8(2), 57-64.

Wang J., McNeel J., Baumgras J. 2003. A computer-based time study system for timber harvesting operations. Forest Products Journal, 53(3), 47-53. 